\title{
Fundamental Movement Skills Game on Intellectual Disability Children in Primary Special Education
}

\author{
$1^{\text {st }}$ Kesumawati, Selvi Atesya \\ Postgraduates Sport Education \\ Semarang State University \\ Semarang Indonesia \\ selvia2_0602511059@ymail.com
}

\author{
$2^{\text {nd }}$ Rahayu, Tandiyo \\ Faculty of Sport Science \\ Semarang State University \\ Semarang Indonesia \\ tandiyorahayu@mail.unnes.ac.id
}

\author{
$3^{\text {rd }}$ Rachman, Hari Amirullah \\ Faculty of Sport Science \\ Yogyakarta State University \\ Yogyakarta Indonesia \\ hari.rachman68@gmail.com
}

\author{
$4^{\text {th }}$ Rahayu, Setya \\ Faculty of Sport Science \\ Semarang State University \\ Semarang Indonesia \\ setyarahayu@mail.unnes.ac.id
}

\begin{abstract}
The Fundamental Movement Skill (FMS) of the intellectual disability (ID) children, whether it is mild or moderate, has a disorder, therefore there is a need to guide the ID of the child on optimal FMS and gain pleasure through movement. Getting game exercise is one form of game designed purposely by researchers for children with mild ID in Primary of Special Education through this game is expected to provide an opportunity to stimulate motor skills, especially the FMS of children with mild intellectual disability repeatedly and can develop ideas according to his own ability. The method used in this research is the research and development of Borg and Gall, the subject of a limited-scale trial of 10 students of Intellectual disability children primary school (SDLBC), and 3 teachers. The subjects of large-scale trials amounted to 30 students in SDLB C in the third SDLB C in the city of Palembang. The FMS game model Let's get exercise designed by researchers is expected to improve fundamental movement skills, cognitive skill, fun and focus attention of children with ID.
\end{abstract}

Keywords-fundamental movement skill, game, intellectual disability children

\section{INTRODUCTION}

Every human being in this world always wants the best in his life, get the best partner, have a decent life, have a healthy body physically and spiritually, not least couples who are waiting for the birth of the baby has the desire, dream and hope which is very big if the baby will be born healthy physically and mentally, then the baby grows and develops healthy, strong, smart and active like normal children, but sometimes the reality is not all in accordance with what is expected because of several factors, there are some parents who get special gift from God, one example is a child born in the condition of the abnormalities that resulted in disturbances in the development of sensormotory.

Children with special needs are children with special characteristics such as intellectual disability (ID) that are different from children in general. ID is a challenge that is hard enough for most parents, not a few parents who complain that taking care and caring for children with ID require extra energy and attention because it is not as easy as doing it in normal children, but parents should address such things positively in order to find the right steps in order to optimize the development and the potential of the child.

The lack of physical activity to be a significant behavioral risk of health among people with ID [3]. Physical activity studies of people with ID identified significant inactivity and associated behavior risks of health in a majority of this population [10]. Physical exercise and various sports-related activities are necessary to promote health, fitness, and psychological development among children of school age. In general, the ability to play sports and exercise is lower for children with intellectual disabilities than in children without such disabilities [6]. Children with intellectual disabilities often have psychological problems associated with carrying out exercise. Moreover, their experience of exercise is limited.

Play activities as a means of enhancing the fundamental movement skills of the ID children listed the following objectives in child-centered play theraphy: (1) help the child enhance his or her possitive self-concept, (2) help the child move to accepting more responsibility for self, (3) help the child reach enhanced levels of self-acceptance, self-reliance, and self-direction, (4) help the child practice self-directed decision making, (5) help the child feel more in control, (6) help the child increase his or her awarness of the process of coping, (7) help the child develop an internal locus of evaluation, (8) help the child learn to trust himself or herself more [7].

The qualitative aspect of the movement displayed by the child, remains dependent on effort, ie how one combines the sharing of elements / factors (time, load, space and flow). Therefore, the idea or theme of movement is essential, meaning that in teaching the movement in children should be tailored to the characteristics of the students. That play should be done on the initiative of the child and on the child's own decision [11]. Play should be done with a sense of fun, so that all play activities are fun will result in a learning process in children. Meanwhile, according to Piaget in Yuliani [2009: 34] said that play is an activity that is done repeatedly and cause pleasure / satisfaction for a person. 
In learning motor skills, children need basic skills experience (locomotor motion, non locomotor and manipulative) [18]. Children should learn to perform simple moves before connecting them into more difficult movements, before mastering a motion skill, children should be given the opportunity to do the exercises. Children should have the opportunity to try, correct and try again. Children will improve their motor skills based on their previous play experience. Memory plays an important role for children in learning motor skills. The child needs to recall what he or she has done in order to correct and correct it. To learn motion skills, children must combine memory or memories with previous experiences, take advantage of opportunities to try something new, and practice what they have learned [14].

Fundamental movement competence is linked to physical activity in both children with and without disability [1]. Locomotors and manipulative skills form the foundation for future movement and are considered essential for the development of more complicated or sport-specific motor skills $[2,15]$. Moreover, locomotor and manipulative skills as indicators of physical skills mastery consequently enabling enjoyable participation in physical activities [5]. Study of correlation between physical activity in children with physical disabilities showed that physical and biological factors such as physical functioning ability and gross motor function were found to be consistently associated with physical activity, suggesting that increased physical and motor functioning is associated with higher levels of physical activity [9].

Play is essential to development because it contributes to the cognitive, physical, social and emotional well-being of children and youth. Play also offers an ideal opportunity for parents to engage fully with their children [4]. Play is a fun activity for children. The game itself can provide an opportunity to practice the skills of the children with intellectual disability repeatedly and can develop ideas according to his own ability, therefore learning pemas should be able to provide opportunities to play in children with intellectual disability in the school environment.

Play is strongly affected by the the child's context, including family and peers, socio-economic influences, and availability of time. What is concidered play by one child may seem totally innappropriate an even distasteful to another child based on his or her prior experiences and personal preferences. Play is viewed as child-initiated activity that is not structured by an adult and does not have skill acquisition as a goal [12].

\section{A. Game Model}

The game Let's Get Exercise is one form of game designed purposely by researchers for children with ID in SDLB C. The Game Name Let's Get Exercise is taken from one of the themes contained in the 2013 Curriculum Master Handbook which is the theme of My Enthusiasm the subtheme is Sports Enthusiasm. The game consists of: Post 1, Post 2 and Post 3. Each post has different basic tasks and motions but is still adjusted to the Competency Standards and Basic Competencies that exist in the Curriculum. The motion tasks that exist in this game is the basic motion goes walk forward, run forward, and underhand rolling and combined with other learning materials such as; simple counting, mentioning / showing images, recognizing color through flashcard media. This game can be implemented at the time of learning at school and can be used as a form of therapy for children tunagrahita at home and done repeatedly so as to improve the basic motion skills of children. The benefits in this game are to stimulate the visual and tactile in the child's tunagrahita in performing the task of motion balance and coordination [Sullivan, et al, 2012: 76-77].

The game aims to; (10) improve the fundamental movement skills of the child with intellectual disabilities, walk forward, run forward and underhand rolling the balls, (2) by looking at the picture on the flashcard the child can name the sports, (3) increase sensory child with texture varies, and (4) recognizes the basic letters, numbers and colors (red, blue and yellow). Equipment Used; six evamatt pieces of $30 \times 30$ centimetres $(\mathrm{cm})$, each modified with a different texture (synthetic grass, large smooth stone, plastic bottle cap, dacron, clay and little stones), box (container) and flashcard with branch / sport shaft, colored tape, flag (marker), and whistles. Instructions; the child stands ready behind the starting line, after hearing the cue from the teacher (whistle) the child immediately performs a straight forward movement on the texture as far as 2.4 metres (6 pieces of modified evamatt of various textures). It is endeavored to keep the child's point of eye focus straight up to the finish line. Once at the end of the line, the child takes one of the flashcards containing the image of the sports stalk and mentions it firmly.

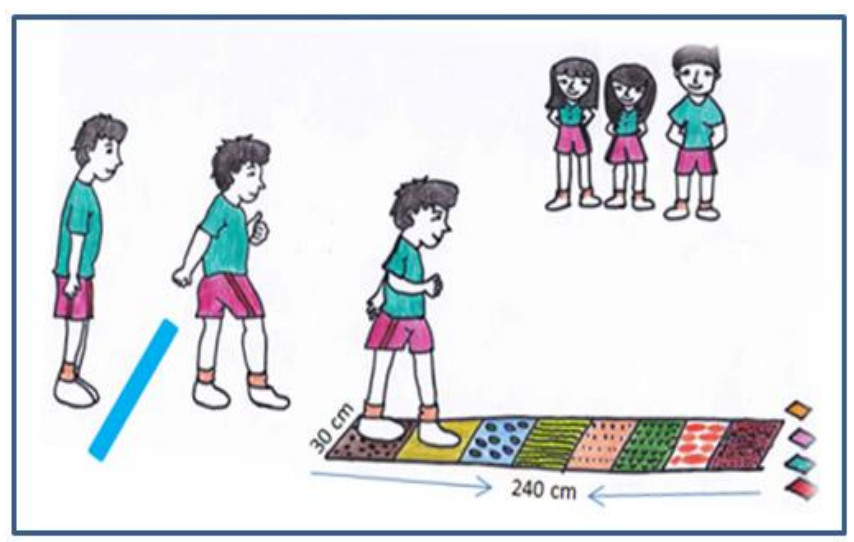

Fig.1. Game Model Post 1 


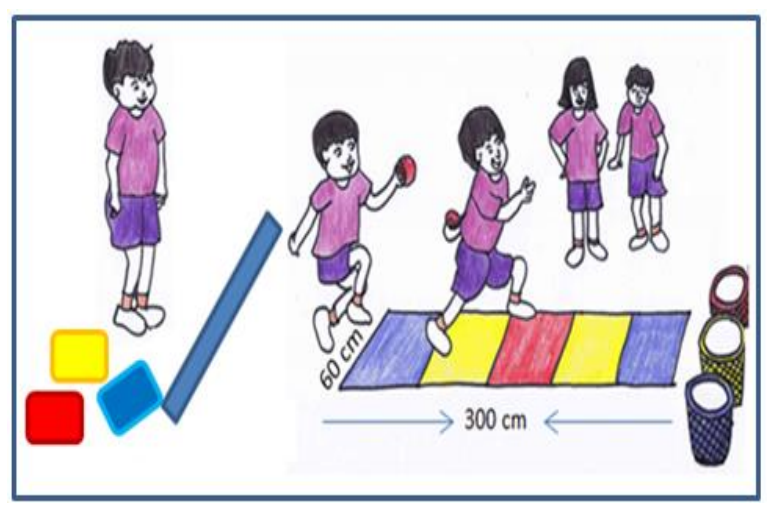

Fig. 2. Game Model Post 2

Equipment used; five pieces of evamatt measuring 60x60 centimetres $(\mathrm{cm})$, three baskets (blue, yellow and red), three basic colored bean bags (red, yellow and blue), tape (colored tape), flag (marker), and whistles. Instructions the game are; the child stands ready behind the starting line. Upon hearing the cue from the teacher (whistle) the child immediately performs a run forward as soon as possible to move 3 pieces of bean bag to the basket that has been provided as far as 3 meters. The child's eyes focus remains straight forward, the arm shaping the elbow opposite to the legs and the body slightly leaning forward during the run, After all the bean bag moved the child back to the starting line, then leave the game area.

Equipment used; Three pieces of rubber ball $15 \mathrm{~cm}$ in diameter, twelve evamatt pieces measuring $60 \times 60 \mathrm{~cm}$, six colored plastic glass (marker), colored tape, and whistles. Instructions; The child stands ready behind the starting line. Upon hearing the cue from the teacher (whistle) the child immediately performs the first underhand rolling the first ball with a distance of 1.5 meters (the child takes the ball with one of his hands, then the child bends the knee while swinging the arm backwards to the next front, eyes focus towards the target and the ball ready to be released / rolled). After rolling the first ball, the child must return to the ready position to roll the second ball with a distance of 2 meters. The child returns to the ready position and moves the last (third) ball with a distance of 3 meters. See figure 3 below :

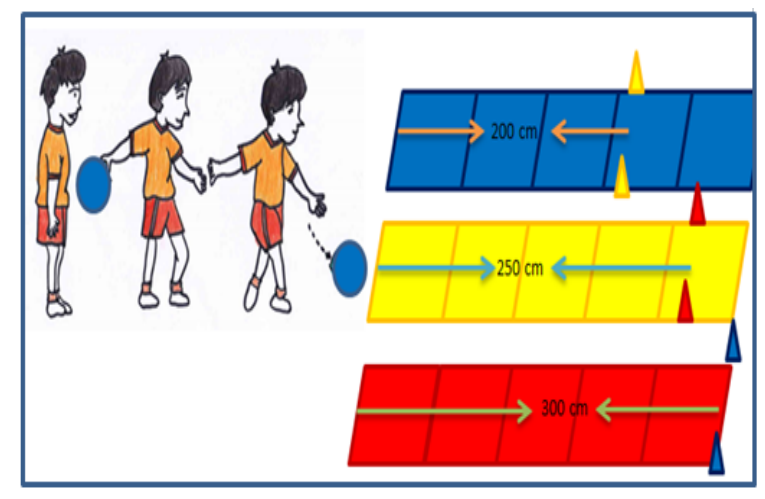

Fig. 3. Game Model Post 3

\section{METHOD}

This study aims to produce a product of a model fundamental movement skill game for intellectual disability children in special education using Borg and Gall's research and development process (R\&D). The subject of the limitedscale trial amounted to 10 students of grade 1 Special Education of Karya Ibu Palembang, 3 teachers (physical educator and teacher class). Extensive trials of 30 people, and 9 teachers (teacher and classroom teachers) Special Education of Palembang City (Karya Ibu, YPAC and Pembina).

\section{CONCLUSION}

The Fundamental Movement Skills (FMS) of the children with mild or moderate intellectual disability has a disorder, therefore a need to guide the child's intellectual disability on optimal FMS and gain pleasure through movement. The FMS game model Let's get exercise designed by researchers is expected to improve fundamental movement skills, cognitive skill, fun and attention focus of the intellectual disability children, so that the child's intellectual disability can live the daily life independently of others.

\section{REFERENCES}

[1] Barnett, L., Hinkley, T., Okely, A., \& Salmon, J. 2013. Child, Family and Environmental Correlates of Children's Motor Skill Proficiency. Journal of Science and Medicine in Sport, 16(4), 332-336.

[2] Capio, C. M., Sit, S. H. P., \& Abernethy, B. 2011. Fundamental Movement Skills Testing in Children with Cerebral Palsy. Disability and Research, 33(25-26), 2519-2528.

[3] Emerson, E. 2005. Underweight, Obesity and Exercise among Adults with Intellectual Disabilities in Supported Accomodation in Northern England. Journal of Intellectual Disability Research, 49(2): 134-143.

[4] Kenneth, R. Ginsburg. 2007. American Journal Academy of Pediatrics, Vol. 119 No. 1, January 1, 2007). 182-191.

[5] Khodaverdi, Z., Bahram, A., Khalaji, H., \& Kazemnejad, A. 2013. Motor Skill Competence and Perceived Motor Competence: Which Best Predicts Physical Activity among Girls?. Iranian Journal of Public Health, 42, 1145-1150.

[6] Kihara, I., Hasimoto, R. 2000. Measurement of Vertical Section of Physical Strength in Children with Mental Disabilities. Japaness Journal of Physical Fitness and Sport Medicine, 49, 887.

[7] Kottman, Terry. 2011 .Play theraphy basic and beyond. United States of America: American Counseling Association.

[8] Kustawan, Dedy and Meimulyani. 2016. Know Special Education and Education of Specialized Services and Implementation. East Jakarta: Luxima.

[9] Li, R., Sit, S. H. P., Yu, J. J., Duan, J. Z., Fan, C. M., \& Wong, S. H. S. 2016. Correlates of Physical Activity in Children and Adolescents with Physical Disabilities: A Systematic Review. Preventive Medicine 89, 184-193.

[10] Moss, SJ. 2009. Changes in Coronary Heart Disease Risk Profile of Adults with Intellectual Disabilities Following A Physical Activity Intervention. Journal of Intellectual Disability Research, 53: 735-744.

[11] Mutiah, D. 2010. Psychology Playing Early Childhood. Jakarta: Kencana.

[12] Parham, L.D., \& L. A. Fazio. 2008. Play in occupational theraphy for children. United States of America; Mosby.

[13] Rosnawati, Ati and Kemis. 2013. Education of Children with Special Needs of Intellectual Disability. East Jakarta: Published; Luxima Metro Media. 
[14] Soetjiningsih. 2002. Child Growth. Mold II, EGC. Jakarta.

[15] Stodden, D. F., Goodway, J. D., Langendorfer, S., Roberton, M. A., Rudisill, M. E. \& Garcia, L. E. 2008. A Developmental Perspective on The Role of Motor Skill Competence in Physical Activity: An Emergent Relationship. Quest, 60, 290-306.

[16] Temple, VA. 2009. Factors Associated with High Levels of Physical Activity among Adults With Intellectual Disability. International Journal of Rehabilitation Research, 32: 89-92.

[17] Widati CH, Sri and Murtadlo. 2007. Adaptive Physical and Sports Education. Jakarta: Ministry of National Education Directorate General of Higher Education Directorate of Manpower.

[18] Yudanto. (2010). Basic Motion Stimulation of Lower Grade Primary School Students. Journal of Indonesian Physical Education, Volume 4, Number 2, November 2007. Faculty of Sport Science, Yogyakarta University. 